\title{
KONVENSYEN HAK KANAK-KANAK 1989: KAJIAN LITERATUR
}

\section{Convention on the Rights of the Child 1989: Literature Review}

\author{
Nor'asyikin Hamzah \\ Ph.D Candidate, Department of Shariah and Law, \\ Academy of Islamic Studies, \\ University of Malaya, 50603 Kuala Lumpur. \\ syikinhamzah@gmail.com \\ Raihanah Hj. Abdullah \\ Professor, Department of Shariah and Law, \\ Academy of Islamic Studies, \\ University of Malaya, 50603 Kuala Lumpur. \\ raihanah@um.edu.my
}

\begin{abstract}
Convention on The Rights of the Child 1989 has opened many discussions and debates on its various of articles provided in the convention from economical, civil, political, social and cultural point of views. Among of them are how existing laws of state parties adhere the standard guidelined in the convention, so that there is no conflict between the existing laws and the convention they ratified. This article based on library research will examine several of selected state parties traced similarities and conflicts between the existing laws and the selected articles of the convention. The study found that there are few of the provisions of the existing laws that comply with the standard of the convention. However, still there are provisions of the existing laws that need amendments in order to fulfill the standard of the convention.
\end{abstract}

Keywords: Convention on the Rights of the Child, 1989, child rights, conflict of laws 


\section{PENDAHULUAN}

Konvensyen mengenai Hak Kanak-kanak 1989 (KHKK) yang mencakupi aspek ekonomi, sivil, politik, sosial dan kebudayaan telah membawa kepada banyak kajian dan perbincangan terhadap peruntukan hak kanak-kanak yang ada di dalam KHKK ini. Isu hak kanak-kanak berkaitan dengan kesihatan, ekonomi, politik, kebudayaan, pendidikan dan undang-undang antara yang banyak dibincang dan diperdebatkan. Bagi isu hak kanak-kanak berkaitan perundangan, kajian yang dibuat menyentuh isu berkaitan kanak-kanak dan jenayah, sivil, ekonomi, politik mahupun keluarga. Isu berkaitan dengan hak kanak-kanak di dalam keluarga antara lainnya melihat sama ada undangundang sesebuah negara pihak kepada KHKK itu selari atau memenuhi standard KHKK ini.

Fokus perbincangan artikel ini merujuk kepada peruntukan hak kanakkanak di dalam undang-undang keluarga negara-negara yang terpilih iaitu Argentina, Canada, Denmark, England, Belanda, Jepun, Mozambique, New Zealand, Poland, Rusia dan Switzerland. Persoalannya sama ada peruntukan dalam undang-undang keluarga negara berkenaan memenuhi standard yang ditetapkan di dalam KHKK ini atau tidak berdasarkan Perkara 2, Perkara 7, Perkara 9(1), Perkara 12 dan Perkara 27(4) KHKK.

\section{PERKARA 2, KHKK: TIADA DISKRIMINASI}

Perkara 2, KHKK memperuntukkan bahawa hak-hak yang dinyatakan di dalam KHKK adalah untuk semua kanak-kanak tanpa sebarang diskriminasi, sama ada bangsa, warna, jantina, bahasa, agama, perbezaan pandangan, warganegara, asal usul etnik atau sosial, harta, hilang upaya, status kelahiran atau status lain kanak-kanak tersebut. Menjadi tanggungjawab pihak kerajaan untuk melindungi kanak-kanak itu daripada sebarang diskriminasi yang telah dinyatakan. Hakikatnya, hak ini bukanlah satu perkara mudah untuk dilaksanakan khususnya bagi anak-anak tidak sah taraf.

Menurut kajian oleh Yukiko Matsushima (1996:132-135), anak-anak tidak sah taraf di Jepun menghadapi isu diskriminasi yang besar seperti merekodkan kanak-kanak di dalam Koseki dan Jumin-Hyo (kad penduduk), iaitu anak sah taraf akan didaftarkan beserta gelarannya sebagai anak pertama atau anak kedua, manakala anak tak sah taraf hanya didaftarkan sebagai 'anak' sahaja, iaitu tanpa gelaran anak pertama atau anak kedua. Anak tidak sah taraf hanya boleh mewarisi separuh sahaja daripada harta yang anak sah taraf berhak mewarisi di bawah peruntukan art. 900(4) Civil Code. Apa yang menarik, 
perbezaan layanan antara anak sah taraf dan tidak sah taraf yang diletakkan di bawah Perlembagaan negara adalah untuk melindungi taraf perkahwinan yang sah dan mengekalkan kehendak sosial.

Walau bagaimanapun, terdapat dua keputusan kes mahkamah yang berbeza di Jepun. Kes yang pertama, mahkamah memutuskan bahawa cucu perempuan daripada anak perempuan yang merupakan anak luar nikah hanya berhak menerima separuh daripada harta datuknya. Kes yang dibawa ke peringkat Mahkamah Rayuan ini telah ditolak, begitu juga ke peringkat Mahkamah Persekutuan. Bagi kes kedua, iaitu tuntutan harta pusaka oleh anak tidak sah taraf ke atas harta ayah biologinya secara sama rata dengan anak-anak sah taraf ayahnya. Mahkamah Tinggi Jepun buat pertama kalinya memutuskan bahawa Perkara 900(4) tidak menurut Perlembagaan, atas alasan antaranya ia menyalahi Perkara 14 Perlembagaan negara itu yang menghalang diskriminasi berasaskan bangsa, kepercayaan atau status sosial. Perkataan "status sosial" ini merujuk kepada kedudukan sosial yang ditentukan semenjak lahir. Pada tahun 1994, Commision Undang-undang Kementerian Keadilan telah membuat cadangan untuk memansuhkan peruntukan Perkara 900(4) Civil Code bahawa anak tidak sah taraf berhak menerima bahagian yang sama seperti yang diterima oleh anak sah taraf dalam bab perwarisan. Kesedaran bertambah untuk merubah undang-undang ini salah satunya disebabkan oleh ratifikasi Jepun ke atas KHKK (Yukiko Matshuhima, 1996: 135-136).

Di Mozambique, Civil Code negara itu adalah konsisten dengan artikel 9 KHKK ini iaitu kanak-kanak yang lahir di dalam keluarga adalah dianggap sebagai anak sah taraf. Manakala anak-anak dilahirkan di luar perkahwinan adalah anak tidak sah taraf, tetapi mereka masih boleh mendapat hak di dalam keluarga menerusi prosedur pengangkatan dan penyiasatan lanjut mengenai kesahtarafan ibu atau bapa ke atas anak itu. Walau bagaimanapun, penulis tidak membincangkan dengan lebih lanjut tentang isu-isu yang berkaitan hak anak dalam keluarga di Mozambique (Luis Filipe Sacremento \& Ana Maria Pessoa, 1996: 148).

Sementara hasil kajian Olga Khazova (1996: 217) mendapati bahawa nasib anak-anak luar nikah di Rusia lebih malang khususnya jika si ibu adalah di bawah umur dewasa di Rusia iaitu 18 tahun bagi lelaki dan perempuan. Sekiranya si ibu berusia bawah 16 tahun dan melahirkan anak luar nikah, menurut Undang-undang Keluarga Persekutuan Russia, menetapkan bahawa dia langsung tidak layak untuk mendaftarkan kelahiran anaknya. Pendaftaran ini hanya boleh dilakukan oleh ibu bapa kandung atau ibu bapa angkat kepada ibu bayi berkenaan. Sekiranya ibu bapa berkenaan enggan melakukan 
demikian, maka ibu bayi ini terpaksa meletakkan anaknya di rumah kanakkanak di bawah jagaan badan kerajaan.

Menurut undang-undang, si ibu boleh meletakkan anaknya sementara di situ dan mempunyai hak untuk mengambilnya pada bila-bila masa. Akan tetapi bagi memohon kepada badan kerajaan tersebut untuk mengambil semula anaknya, badan kerajaan 'mencadangkan' supaya ibu itu memberi kebenaran agar anaknya itu boleh diambil sebagai anak angkat pada bila-bila masa. Ini bermakna, bagi ibu yang telah meletakkan anaknya di bawah jagaan badan kerajaan tersebut, dia tidak akan dapat mengambil semula anaknya jika anaknya telah diambil sebagai anak angkat. Pengangkatan anak-anak di Rusia adalah satu permintaan yang tinggi (Olga Khazova, 1996: 217-218).

Ibu muda yang mendapati diri mereka berada di dalam situasi di atas diletakkan di bawah tekanan yang hebat, sama ada daripada pentadbiran hospital bersalin dan pihak berkuasa tempatan, atau ibu bapa mereka, atau kesemua mereka keseluruhannya. Akibat daripada taraf kehidupan yang miskin serta usia yang masih muda, mereka gagal menyedari kesan daripada tindakan mereka. Dalam masa yang sama, undang-undang juga tidak melindungi mereka, serta mereka dijadikan barang permainan di tangan orang dewasa. Oleh itu, Olga Khazova mencadangkan sebagai peringkat permulaan, undangundang mesti memperuntukkan bahawa kebenaran kepada pengangkatan perlu diberikan oleh orang yang benar-benar cukup umur dan bukan kanakkanak seperti yang berlaku pada ibu muda di bawah umur 18 (Olga Khazova, 1996: 218).

Berbeza dengan nasib anak-anak luar nikah di Argentina yang mana mereka menikmati hak yang sama dengan anak-anak sah taraf khususnya dalam mendapatkan hak kesahtarafan, iaitu anak tidak sah taraf berhak dinasabkan dengan bapa biologinya melainkan bapa biologi tersebut menafikan anak itu sebagai anaknya dengan menjalani prosedur ujian biologi dan keputusan ujian itu memihak kepada penafian si bapa. (Cecilia P.Grosman, 1996: 12-13).

\section{PERKARA 7, KHKK: HAK UNTUK MENDAPATKAN NAMA DAN KERAKYATAN}

KHKK mengiktiraf bahawa kanak-kanak yang selamat dilahirkan berhak mempunyai nama dan hak untuk mengenali ibu bapanya. Kelahirannya ini berhak didaftarkan dan diberikan kerakyatan serta mempunyai hak semenjak lahir. Proses pendaftaran dan perlaksanaan hak ini menjadi tanggungjawab kerajaan untuk melaksanakannya mengikut undang-undang negara masingmasing (Perkara 7). 
Walaupun begitu, tidak semua kanak-kanak dapat mengenali ibu bapa mereka kerana faktor asal usul kelahiran anak itu sendiri seperti yang berlaku di Argentina. Di Argentina, apabila si anak dilahirkan di luar perkahwinan dan bapa biologi itu enggan menjalani ujian pengesahan kebapaan seperti ujian darah, ini akan menyukarkan perjalanan sebarang kes tuntutan hak si anak di mahkamah. Ini kerana pembuktian biologi tidak dapat dikemukakan disebabkan hak anak tidak sah taraf adalah sama di dengan anak sah taraf (Cecilia P.Grosman, 1996: 12-13).

Sementara itu, Stojanowska and Elżbieta Holewińska-Łapińska (1996) mendapati bahawa Kerajaan Poland telah melakukan reservasi terhadap Perkara 7, KHKK. Ini kerana kehendak anak-anak angkat untuk menemui ibu bapa kandungnya adalah terhad disebabkan undang-undang negara tersebut membenarkan ibu bapa angkat merahsiakan asal usul anak itu. Keputusan untuk memberitahu anak angkat tentang fakta pengangkatannya terletak pada ibu bapa angkat kerana ia adalah hal dalam keluarga (Stojanowska and Elżbieta Holewińska-Łapińska,1996:201). Di sini jelas undang-undang menjadi kekangan kepada seseorang anak untuk mengetahui siapa ibu bapa kandungnya.

Kini, kelahiran bayi tidak lagi bergantung kepada kaedah konvensional (hubungan seks) semata-mata, tetapi dimajukan dengan teknologi perubatan moden seperti persenyawaan berbantu (artificial insemination by donor or egg donation). Tetapi ia menjadi isu di mana adakah anak ini berhak untuk mengenali ibu bapa genetiknya itu? Situasi ini berlaku di Denmark dan Poland. Jika di Denmark, isunya berkitar penderma sperma sahaja iaitu penderma sperma tidak mahu dikenali sebaliknya hanya mahu membantu wanita hamil dan mempunyai zuriat sendiri, serta tidak mahu dianggap sebagai bapa kepada anak tersebut. (Linda Nielsen dan Lis Frost, 1996: 73-74) tetapi di Poland ia termasuk juga isu penderma ovum oleh wanita lain ke dalam rahim wanita lain (Stojanowska and Elżbieta Holewińska-Łapińska, 1996: 201). Walau bagaimanapun, undang-undang Poland tidak menguruskan perkara ini dan tidak akan melakukannya kerana pihak Gereja Katolik memandang negatif akan pendekatan ini. Justeru, tidak ada asas di dalam sistem perundangan negara ketika itu berhubung penetapan penderma sperma sebagai bapa dan wanita yang menghamilkan anak itu dianggap sebagai ibu. Akibatnya, anak-anak yang lahir melalui prosedur ini tidak dapat mengetahui asal usul keturunannya (Wanda Stojanowska and Elżbieta Holewińska-Łapińska, 1996: 201).

Sementara di Denmark, Linda Nielsen dan Lis Frost (1996: 73-74) mendapati isu mengenai kerahsiaan penderma sperma hangat diperdebatkan 
seperti laporan oleh The Danish Council of Ethics. Perdebatan berlaku antara pendapat majoriti yang mahu mengekalkan prinsip kerahsiaan penderma manakala pendapat minoriti mahukan keterbukaan mengenai pendermaan sperma telah berlaku dan identiti penderma. Satu laporan yang dikeluarkan oleh ahli jawatankuasa sementara di Kementerian Kesihatan Denmark berhubung pendapat majoriti yang mahu mengekalkan kerahsiaan penderma sperma bahawa tujuan penderma rahsia itu adalah untuk membantu orang lain hamil dan mempunyai anak. Penderma tidak mahu dianggap sebagai ayah kepada mana-mana bayi yang dilahirkan melalui prosedur ini. Berhubung soal anak pula, pihak jawatankuasa menekankan aspek pembesaran kanak-kanak dan hubungan kekeluargaannya yang perlu dibuat sedapat mungkin normal seperti kanak-kanak lain. Laporan ini menolak pendapat bahawa penting untuk si anak mengetahui asal usulnya.

Manakala kajian yang dijalankan oleh Mark Henaghan (1996: 186) di New Zealand mendapati bahawa Status of Children Amendment Act 1987 yang diluluskan telah mengubah status kanak-kanak yang dilahirkan hasil teknologi perubatan yang mana penderma (ibu bapa biologi kanak-kanak) itu tidak akan menjadi ibu bapa anak itu di sisi undang-undang. Sebaliknya, undangundang mengiktiraf suami isteri yang menerima anak itu sebagai ibu bapa sah. Tetapi tidak ada keperluan di sisi undang-undang bahawa maklumat identiti asal kanak-kanak itu dirahsiakan demi kebaikan anak itu (Mark Henaghan, 1996: 186). Pada pandangan penulis, di bawah akta ini, kanak-kanak itu akan dinafikan terus haknya untuk mengenali ibu bapa biologinya melainkan atas ehsan ibu bapa angkatnya untuk memberitahu identitinya yang sebenar.

Berlainan dengan Switzerland, Perkara 24 Novies (g) Perlembagaan negara itu mengiktiraf hak anak untuk mengenali ibu bapanya (Olivier Guillod, 1996; 233). Walaupun peruntukan ini adalah sebahagian peruntukan berkaitan dengan genetik dan rawatan penciptaan berbantu (medically assisted procreation), tetapi ramai yang beranggapan hak untuk mengenali ibu bapa ini bukan sahaja di dalam kes kanak-kanak yang dilahirkan secara berbantu dengan penderma sperma dan ovum, tetapi juga anak-anak angkat. Bahkan penemuan Guillod mendapati, undang-undang Swiss adalah melangkaui Perkara 7 (2) KHKK yang mengiktiraf hak kanak-kanak untuk mengenali ibu bapanya as far as possible (sebanyak mungkin). Menurut beliau lagi, peruntukan KHKK ini tidak terpakai kepada persenyawaan berbantu, kerana penderma sperma ini tidak boleh dikatakan bapa berdasarkan KHKK. Jelas di sini, Switzerland mengiktiraf hak kanak-kanak itu untuk mengetahui ibu bapanya sendiri tanpa mengira ia dilahirkan melalui perkahwinan atau bantuan teknologi perubatan moden, mahupun dia menjadi anak angkat kepada keluarga lain. 
Berbeza dengan hak kanak-kanak luar nikah untuk dibesarkan oleh ibu bapanya langsung tidak dinyatakan di dalam perundangan Rusia (Olga Khazova, 1996: 215). Ternyata ia bertentangan dengan artikel 7 KHKK ini. Paling ketara apabila di dalam satu peruntukan undang-undang yang diperkenal pada 1944, membenarkan ibu menyerahkan anak luar nikahnya kepada institusi kanak-kanak di bawah pentadbiran kerajaan tanpa mengira sebab musabab dia melakukannya.

Begitu juga kritikan Olga Khazova terhadap Seksyen 48 Code on Marriage and the Family, berhubung keperluan bukti yang boleh dipercayai oleh mahkamah untuk mewujudkan kesahtarafan bapa ke atas anak. Ini bermakna, jika si bapa enggan menjalani ujian untuk menguji kesahtarafannya sebagai bapa, maka si anak tidak dapat menerima haknya sebagai anak. Bahkan Olga merujuk kepada hasil kajian oleh A.I Pergament dan E.A. Pavlodskii (1988) bahawa setiap lima kes permohonan untuk mewujudkan kesahtarafan anak, adalah ditolak oleh mahkamah. Ini bermakna, hak anak untuk mengenali bapanya terhalang disebabkan oleh pihak mahkamah dan keengganan si bapa sendiri (Olga Khazova, 1996: 215-216). Justeru, menurut Olga Khazova, hak kanak-kanak di bawah Perkara 7 KHKK ini tidak dapat dilaksanakan di Rusia kerana sistem perundangan yang tidak membantu.

\section{PERKARA 9(1) KHKK: HAK HIDUP BERSAMA IBU BAPA}

Jika kanak-kanak berhak mengenali ibu bapanya, bermakna ia berhak hidup bersama mereka. Malangnya ramai kanak-kanak tidak dapat menikmati hidup bersama keluarga, seperti anak-anak jalanan yang ditinggalkan, lari daripada rumah, didera oleh ibu bapa, dan dijual. Sebagai contoh, masalah jual beli kanak-kanak di Argentina berlaku kerana kemiskinan dan ibu yang menyerahkan anaknya kerana tidak mendapat bantuan keluarga (Cecilia P.Grosman, 1996: 11 \& 20)

Perkara 9(1) KHKK ini memperuntukkan bahawa kanak-kanak tidak dipisahkan daripada ibu bapanya tanpa kerelaannya kecuali jika ia adalah untuk kepentingan terbaik kanak-kanak itu. Di bawah undang-undang Argentina, terdapat keadaan-keadaan yang menjustifikasikan kanak-kanak dipisahkan daripada ibu bapanya. Antaranya seperti jenayah ke atas anak, meninggalkan anak, menjejaskan keselamatan, menunjukkan contoh yang buruk, membahayakan fizikal, kesihatan mental atau moral anak-anak, layanan buruk, juvana, dan lain-lain. Mereka ditempatkan di penginapan sementara yang disediakan oleh kerajaan (Cecilia P.Grosman, 1996: 17). 
Cecilia P. Grossman (1996: 17) mencadangkan, oleh kerana ibu bapa tidak dapat berfungsi dengan baik, maka kanak-kanak yang menghadapi risiko-risiko di atas perlu dikeluarkan daripada keluarga bermasalah ini dengan campurtangan kerajaan. Untuk memenuhi kehendak KHKK, perkara utama perlu dilakukan kerajaan ialah dengan memenuhi keperluan keluarga, membolehkan mereka menjaga anak mereka dengan secukupnya dan memenuhi tanggungjawab ibu bapa. Dalam kata lain, memperbaiki taraf ekonomi keluarga, membuat program menentang keganasan rumahtangga dan membantu keluarga yang berhadapan krisis dadah atau penyalahgunaan dadah.

Walaupun Perkara 9(1) KHKK memperuntukkan keputusan untuk memisahkan kanak-kanak daripada ibu bapanya yang bertentangan dengan kehendaknya mesti diambil kira oleh pihak berkuasa yang berkelayakan bergantung kepada pandangan penghakiman, tetapi Olivier Guillod (1996: 235) mendapati tidak semua keputusan dalam perkara ini bergantung pada pandangan penghakiman di bawah undang-undang Swiss masa itu. Sejumlah bilangan pihak berkuasa yang berkelayakan bukan kehakiman, dan Perkara 314 dan 314(a) Civil Code memerlukan pandangan undang-undang hanya pada kes-kes yang menghalang kuasa ibu bapa dan menghalang kebebasan kanak-kanak untuk bantuan peribadi.

Sementara di New Zealand, Akta Children, Young Persons and Their Families 1989 memperuntukkan jika kanak-kanak itu perlu dipisahkan daripada ibubapa kandungnya, kanak-kanak itu mesti diletakkan dengan mana-mana ahli keluarganya atau sekurang-kurangnya dengan orang dewasa yang mempunyai kebudayaan yang sama (Mark Henaghan, 1996: 186).

Sementara Olivier Guillod (1996: 231-232) mendapati peraturan negara Switzerland berhubung dengan pendudukan adalah tidak selari Perkara 9 dan 10 (hak untuk bersatu dengan keluarga) KHKK. Ini kerana mereka menafikan beberapa hak orang luar yang tinggal di Switzerland untuk membawa keluarga mereka bersama, terutama kes-kes yang melibatkan pekerja-pekerja memiliki permit pekerjaan sementara. Begitu juga dengan orang-orang yang berkuasa untuk tinggal di Switzerland dalam tempoh sementara, mereka dinafikan hak untuk bersatu bersama keluarga. Sudah pasti ia memberi kesan kepada kanak-kanak untuk bersatu dengan ibu bapa mereka, jika salah satu pihak yang memiliki permit pekerjaan sementara atau tinggal sementara di Switzerland.

Berhubung dengan kes perceraian di Argentina, hak penjagaan anak-anak biasanya diberikan kepada ibu sekiranya si anak berusia bawah 5 tahun. Bagi anak yang berusia 5 tahun ke atas, sekiranya ibu bapa yang bercerai gagal mencapai persetujuan, maka anak itu akan diamanahkan kepada ibu atau bapa yang hakim fikirkan lebih sesuai untuk menjaganya (Perkara 206, Civil 
Code). Walau bagaimanapun, dalam amalan penghakiman, sama ada dengan persetujuan atau perintah mahkamah, anak tersebut lazimnya kembali kepada ibu (Cecilia P.Grossman, 1996: 18).

Manakala di Denmark, kedudukan anak tidak sah taraf dengan anak sah taraf adalah sama di dalam perundangan di dalam aspek pewarisan dan nafkah tetapi tidak di dalam hak penjagaan anak. Bagi penjagaan anak sah taraf selepas perceraian, penjagaan anak boleh dibuat sama ada jagaan bersama atau salah satu pihak yang bercerai mendapat hak jagaan yang diputuskan di mahkamah. Sekiranya ibu bapa tidak mencapai persetujuan tentang penjagaan anak ini, mahkamah akan memutuskannya berdasarkan prinsip kepentingan terbaik kanak-kanak (best interest of the child). Isu utama dalam kes ini ialah perebutan hak jagaan anak oleh pasangan bersekedudukan yang telah berpisah, khususnya oleh si bapa yang menuntut hak berkongsi penjagaan anak kerana si ibu sahaja yang mendapat hak penjagaan. Walau bagaimanapun, mereka masih boleh membuat penjagaan bersama. Sekiranya mereka gagal mencapai persetujuan bersama, maka mahkamah akan menentukannya berdasarkan prinsip kepentingan terbaik kanak-kanak (Linda Nielsen dan Lis Frost, 1996: 69).

Berdasarkan Akta 14 Jun 1995, beberapa pindaan undang-undang telah dilakukan berkaitan hak penjagaan dan hak lawatan; hak penjagaan bersama secara automatik berdasarkan kepentingan kanak-kanak untuk pasangan ibu bapa yang bersekedudukan di dalam hubungan yang stabil dimansuhkan daripada akta terkini kerana ia dianggap mustahil untuk membezakan antara ibu yang bersekedudukan dengan ibu tunggal di mana hubungan dengan si bapa mungkin tiada; memperkenalkan kekerapan melawat anak-anak bagi pihak yang tidak mendapat hak penjagaan; prosedur perpindahan hak penjagaan kepada bapa yang tidak berkahwin selepas tamat sekedudukan di buat dengan lebih mudah (Linda Nielsen dan Lis Frost, 1996:72).

Berkenaan dengan hak lawatan pula, daripada segi peruntukan undangundang, undang-undang Argentina seiring dengan peruntukan Artikel 9(3) KHKK yang memberikan hak untuk berhubung di antara anak dengan ibu bapa yang tidak mendapat hak jagaan. Di dalam semua bentuk perceraian, ibu bapa yang mendapat hak penjagaan berhak melaksanakan hak ibu bapa, bagi pihak yang satu lagi mendapat hak untuk berhubung dengan secukupnya dan melihat tumbesaran anaknya (Cecilia P. Grosman, 1996: 18).

Walaupun begitu, pada hakikatnya anak-anak dianggap sebagai objek harta ibu bapa apabila ibu bapa bercerai terutama konflik pasangan yang bercerai melibatkan nafkah yang memberi kesan buruk pada si anak. Dalam konflik ini, bapa biasanya akan berhenti menemui anak mereka dan sekali gus tidak 
mengambil berat tentang pendidikan tumbesaran anak-anak. Ada juga ibu yang menghalang bapa daripada bertemu dengan anaknya. Lawatan hanya akan dihentikan sekiranya kelakuan ibu bapa yang bukan penjaga merosakkan si anak atau menggugat kesihatan mental atau fizikal si anak (Cecilia P. Grossman, 1996: 19).

Terdapat kes penarikan balik hak penjagaan bagi ibu bapa yang menghalang salah seorang daripada mereka untuk berjumpa dengan si anak. Undangundang telah diluluskan untuk memenjarakan ibu bapa atau pihak ketiga yang menghalang hubungan antara anak kecil dan ibu bapa yang tidak tinggal bersama. Denda juga dikenakan ke atas pihak yang menghalang akses terhadap anak-anak dengan menukar alamat kediaman tanpa kebenaran pihak berkuasa. Ini berlaku apabila ibu bapa membawa anak keluar negara tanpa keizinan pihak mahkamah (Law 24.27/930) (Cecilia P. Grossman, 1996: 19).

Di dalam amalan penghakiman juga, bapa ditamatkan hak untuk melawat kerana gagal membayar nafkah berdasarkan permintaan si ibu. Tetapi kecenderungan sekarang ialah mengekalkan hubungan dengan bapa kerana ini merupakan hak asas seorang anak dan menafikannya umpama mengenakan dua hukuman iaitu anak tidak mendapat nafkah dan berhubung dengan bapanya. Cecilia P.Grossman (1996: 30) mencadangkan supaya hak untuk berhubung perlulah diberikan juga kepada si anak, bukan hak ibu bapa semata-mata bagi mengharmonikan sistem undang-undang sedia ada dengan KHKK. Hak ini telah diakui di dalam doktrin dan keputusan penghakiman.

Beliau juga mencadangkan bagi memastikan prinsip ibu bapa bersama menjaga anak-anak selepas perceraian supaya anak-anak terus berhubungan dengan kedua ibu bapa, undang-undang Argentina hendaklah menerima penjagaan bersama. Ini kerana berdasarkan amalan sebelum ini, mahkamah Argentina biasanya menolak perjanjian penjagaan bersama kerana bimbang ia akan memberi kesan kepada tumbesaran anak. Salah satu daripada isu terkini yang perlu dihadapi ialah bagaimana undang-undang perlu berjalan untuk mengekalkan hubungan dengan kedua-dua ibu bapa apabila salah seorangnya dijangkiti penyakit AIDS (Cecilia P.Grossman, 1996: 19-20).

Bagi Kesatuan Bapa di Denmark, mereka mendakwa ketidakadilan berlaku kerana bapa yang mempunyai anak luar nikah ini tidak mendapat hak berkongsi tanggungjawab keibubapaan secara automatik. Bahkan The Danish Centre of Human Rights bimbang sama ada peruntukan ini bertentangan dengan Perkara 18 KHKK kerana hak lawatan bapa gagal untuk membolehkannya menunaikan tanggungjawab dan menentukan aspek tumbesaran dan perkembangan si anak. Peruntukan ini juga bertentangan dengan Perkara 2 KHKK yang melarang diskriminasi terhadap anak-anak tanpa mengira status. Dalam hal ini, adalah menjadi hak bagi anak luar nikah itu untuk dibesarkan oleh bapa biologinya 
secara bersama dengan si ibu sekiranya telah bercerai. Human Rights Centre ini juga berpendapat bahawa ibu atau bapa yang tidak mendapat hak penjagaan tetapi mempunyai hak lawatan, sepatutnya mempunyai hak juga untuk mendapat apa jua maklumat berkaitan kehidupan anaknya. Contohnya dalam bab persekolahan dan penyakit, melainkan jika ia bertentangan dengan kepentingan terbaik anak-anak. Bukan itu sahaja, mereka juga patut diberikan hak untuk melarang hasrat pihak yang mendapat hak jagaan untuk membawa anak berpindah ke luar negara (Linda Nielsen dan Lis Frost, 1996: 69-70).

Sementara kajian yang dijalankan oleh Coby de Graaf (1996: 15) di Belanda mendapati Perkara 1:161a dalam Dutch Civil Code (DCC) adalah konsisten dengan Perkara 9(3) KHKK. Hakikatnya di Belanda, biarpun terdapat peruntukan berkenaan, namun agak sukar untuk memastikan hak itu boleh dilaksanakan oleh kanak-kanak. Ini kerana kanak-kanak tidak mempunyai hak yang formal sama seperti ibu bapa mereka untuk membuat permohonan melalui penyelesaian mahkamah. Walau bagaimanapun, menurut Perkara 162a DCC, kanak-kanak berusia 12 tahun dan ke atas mempunyai akses secara tidak langsung ke mahkamah seperti menelefon mahkamah tanpa melalui permohonan bertulis. Mahkamah boleh membuat satu keputusan ex officio, apabila menjadi kehendak kanak-kanak, tetapi ia juga boleh difahami bahawa terserah pada budi bicara mahkamah untuk menyiasat atau tidak, akan perkara tersebut.

Di dalam aspek lain, di bawah rang undang-undang keluarga yang baru, peruntukan 161a ditambah bahawa ahli keluarga lain juga mempunyai hak melawat si anak termasuklah datuk, nenek, ibu bapa tiri dan bapa kandung, dengan syarat jika mereka ini mempunyai hubungan kekeluargaan yang sebenar dengan si anak. Ini dianggap mengagumkan oleh penulis artikel tersebut kerana sebelum ini tidak pernah ada kemungkinan membenarkan hak melawat antara adik beradik (Coby de Graaf, 1996: 17).

Di Jepun pula, tidak ada peruntukan di dalam Civil Code yang menjelaskan hak lawatan, akan tetapi hak ini telah diiktiraf dalam kes Law Art. 766(1) Civil Code yang menyatakan hak jagaan dan lain-lain perkara yang perlu untuk seorang kanak-kanak ditentukan ketika perceraian dengan kebenaran, dan Mahkamah Agung (Supreme Court) telah menentukan bahawa hak melawat anak selepas perceraian adalah salah satu daripada perkara-perkara ini. Hakikatnya, kajian menunjukkan bahawa $61 \%$ kes perceraian tidak ada hubungan (contact) antara bapa dan anak. Manakala 11\% masih ada hubungan tetapi lama-kelamaan hubungan itu putus, dan 26\% masih kekal berhubung dengan anak mereka. Ini disebabkan oleh tindakan si ibu yang menghalang anak-anak daripada menemui bapa mereka. Bahkan si ibu juga lebih suka 
memutuskan hubungan dengan bekas suami mereka apabila diceraikan dengan sebab keganasan suami, perzinaan atau ditinggalkan. Namun, ada juga ibu bapa memaksa untuk menemui anak-anak di luar kehendak si anak (Yukiko Matshushima, 1996: 137).

Yukiko Matshushima (1996:138), menyarankan bahawa hak lawatan patut ditentukan dalam konteks kepentingan terbaik kanak-kanak dan tidak bergantung pada keegoan atau kepentingan diri ibu bapa. Sehingga sekarang hak lawatan semata-mata di atas kehendak ibu bapa. Tetapi kehendak anak untuk berjumpa ibu atau bapanya selepas perceraian patut menjadi hak yang sedia wujud.

\section{PERKARA 12 KHKK: HAK UNTUK DIDENGAR}

Perkara 12, KHKK memberikan hak kepada kanak-kanak untuk memberikan pendapatnya di dalam mahkamah, khususnya berhubung dengan hak penjagaan (Stephne J.Toope, 1996; Linda Nielsen dan Lis, 1996; Yukiko Matsushima, 1996), hak lawatan, penempatan di luar rumah dan pengangkatan (Linda Nielsen dan Lis, 1996 ;Cecilia P.Grossman, 1996; Yukiko Matsushima, 1996).

Di Kanada, di dalam kes-kes perceraian kepentingan kanak-kanak di dalam soal penjagaan adalah dilindungi oleh mahkamah setelah mendengar pertikaian ibu bapa. Walaupun begitu, pandangan kanak-kanak bukanlah satu keperluan di dalam semua bidangkuasa mahkamah. Dalam keadaan-keadaan tertentu, kanak-kanak akan diwakili oleh peguam yang berasingan (Stephne J.Toope, 1996: 55).

Di Argentina, pandangan kanak-kanak diterima di dalam mahkamah khususnya apabila kedua ibu bapa tidak bersetuju dalam menjalankan tanggungjawab keibubapaan, atau ada masalah dengan hak penjagaan ataupun hak lawatan. Hakim akan mendengar pembuktian daripada kanak-kanak jika kanak-kanak itu cukup memahami dan boleh dinasihati untuk menentukan apa yang terbaik bagi kepentingan kanak-kanak tersebut. Begitu juga di dalam kes pengangkatan, hakim akan mendengar pandangan anak angkat khususnya yang berusia lebih 10 tahun. Jika ibu bapa angkat itu mempunyai anak kandung, pandangan anak itu juga akan didengar semasa perbicaraan jika hakim merasakan ia perlu dan mereka berusia lebih 8 tahun (Cecilia P.Grossman, 1996: 23-24).

Di Denmark pula, kanak-kanak dan orang muda di bawah umur 18 tahun adalah di bawah jagaan (guardianship) dan individu yang mempunyai hak sebagai ibu bapa dipertanggungjawabkan untuk menjaga si anak dan boleh membuat keputusan untuknya berdasarkan kepentingan dan keperluan anak 
itu (Minors' Act, s. 7; Custody Act, s. 2). Hakikatnya, tidak ada peruntukan umum di dalam undang-undang Denmark yang boleh dibandingkan dengan Perkara 12, KHKK ini, tetapi ada peruntukan-peruntukan tertentu berhubung hak untuk didengar ini telah digubal sekian lama (Linda Nielson \& Lis Frost, 1996: 84).

Di dalam kes penjagaan atau lawatan di Denmark, anak-anak yang berusia 12 tahun boleh memberi pandangan mereka tetapi ia bukan satu kemestian. Mahkamah juga mendengar pendapat kanak-kanak di bawah usia 12 tahun. Perbincangan ini boleh dilakukan di mana sahaja termasuklah di dewan mahkamah atau dalam bilik hakim atau gabenor dan tidak ada prosedur khusus untuk dipatuhi dan diikuti. Dalam kebanyakan kes, ibu bapa tidak akan hadir bersama, sebaliknya pakar kanak-kanak akan hadir bersama. Pihak berkuasa boleh menamatkan temu bual jika ia memberi keburukan kepada anak dan boleh tidak menggunakan hasil temu bual itu jika difikirkan ia tidak ada kepentingan di dalam membuat keputusan. Dalam keadaan kedua ibu bapa bersetuju tentang penjagaan, pandangan anak-anak tidak akan didengar kerana kebiasaannya kehendak ibu bapa akan dituruti. Begitu juga dengan perpisahan ibu bapa yang bersekedudukan yang bersetuju dengan penjagaan, maka pandangan anak-anak tidak akan didengar (Linda Nielson dan Lis Frost, 1996: 84).

Persoalan yang timbul ialah adakah semua anak akan bersetuju dengan kehendak ibu bapa mereka, ataupun sebaliknya. Ini kerana ia melibatkan si anak itu akan tinggal bersama dengan satu pihak dalam jangka masa lebih lama dan panjang berbanding dengan satu pihak yang hanya datang melawat.

Namun (Linda Nielson \& Lis Frost, 1996: 85) mendapati situasi lain berlaku pada hak lawatan. Gabenor daerah dimestikan untuk membuat perbincangan dengan kanak-kanak yang telah berusia 12 tahun. Kanakkanak inilah menentukan sama ada mereka hendak melawat ibu bapa atau tidak. Keputusan berkenaan hak lawatan secara prinsipnya dilaksanakan oleh Bailif, tetapi jika kanak-kanak itu jelas menolak keputusan itu, Bailif tidak akan menguatkuasakan keputusan itu kerana ia dilihat sebagai merosakkan kebajikan kanak-kanak itu. Hak lawatan ini diformulakan sebagai hak untuk ibu bapa yang tidak mendapat penjagaan tetapi hak ini juga tidak mengenakan tanggungjawab bagi si anak untuk berjumpa ibu bapanya itu.

Di parlimen Denmark, timbulnya persoalan sama ada kedudukan dominan oleh pemegang penjagaan dan persetujuan mereka adalah bertentangan dengan Perkara 16 (hak privasi) dan Perkara 13-15 (hak kebebasan bersuara, berfikir, beragama, berpersatuan dan berkumpul dengan tenang) KHKK. Tetapi ia dirumuskan bahawa undang-undang Denmark konsisten dengan KHKK 
kerana Perkara ini perlu diterjemahkan bersama Perkara 5, yang mana negara mesti menghormati tanggungjawab ibu bapa, hak dan tanggungjawab mereka (Linda Nielson \& Lis Frost, 1996: 85).

Di England, Michael Freeman (1996: 96-97) mendapati peruntukanperuntukan di dalam Children Act adalah konsisten dengan Perkara 12 KHKK khusus berkaitan dengan bidang perubatan seperti membenarkan kanak-kanak mendapat pemahaman yang secukupnya untuk membuat keputusan menjalani sesuatu rawatan yang membolehkannya untuk menolak atau menerima (informed consent). Tetapi ia dilihat tidak konsisten khusus berkaitan dengan pertikaian private law seperti perceraian. Agak sukar untuk melihat kehendak dan perasaan kanak-kanak dipertimbangkan atau diwakili. Bahkan apabila melihat kepada akta tersebut berhubung kes perceraian, ia lebih cenderung kepada parent-centred berbanding child-centred.

Di Jepun, Yukiko Matshushima (1996: 138) mendapati dalam kes-kes perceraian, mahkamah keluarga mempunyai tugas perundangan untuk mendengar kenyataan (statement) kanak-kanak berusia 15 tahun dan ke atas sebelum membuat keputusan berhubung hak penjagaan. Di dalam amalan mahkamah keluarga, kanak-kanak berusia 10 tahun ke atas akan ditanya pendapat mereka. Oleh itu, boleh dikatakan bahawa pandangan kanakkanak mampu diterima. Tetapi bagi perceraian dengan kebenaran, yang berjumlah $90 \%$ daripada keseluruhan perceraian, tidak ada sistem untuk memeriksa pendapat kanak-kanak. Oleh itu, pendapat kanak-kanak wajar didengar walaupun di dalam kes-kes perceraian dengan kebenaran, sama ada ia dirujuk ke mahkamah keluarga atau beberapa khidmat awam dalam memastikan kebajikan kanak-kanak tersebut terjaga. Persatuan Peguam juga telah mencadangkan satu sistem yang berdikari bagi wakil istimewa (special representative) patut ditubuhkan. Wakil ini akan menjaga kepentingan kanakkanak ketika mediasi, perbicaraan atau situasi penyelesaian perceraian yang dipersetujui.

Di New Zealand, pandangan kanak-kanak di dalam mahkamah masih dalam tempoh percubaan dan lebih kepada ketidakwujudannya. Menurut Mark Henaghan (1996: 173), Perkara 12 KHKK tidak semudah itu menyerahkan membuat keputusan kepada kanak-kanak. Ia mengiktiraf kanakkanak mempunyai pandangan yang perlu diberi pertimbangan mengikut umur dan kematangan kanak-kanak. Perkara 12 KHKK lebih kepada menilai dan menerima perkara-perkara di dalam cara yang berbeza berbanding dewasa. Perkara 12 KHKK mempunyai kesan yang begitu kuat untuk meminta kepada pembuat keputusan untuk mendengar dan memahami dunia kanak-kanak. 
Ini tidak bermakna, pandangan kanak-kanak tidak didengar langsung di mahkamah. Dalam perbicaraan mengenai pengangkatan (Adoption Act 1955), hak penjagaan dan lawatan (Guardianship Act 1968), pandangan kanak-kanak diambil kira oleh mahkamah, namun dalam keadaan yang terhad. Sebagai contoh, di dalam kes penjagaan dan lawatan, sekiranya pasangan suami isteri melalui proses kaunseling dan mediasi untuk menyelesaikannya, maka pandangan kanak-kanak tidak didengar atau diambil kira. Sebaliknya, jika kes ini perlu dibawa ke mahkamah, ia merupakan mandatori untuk melantik peguam mewakili kanak-kanak itu.

Begitu juga di dalam Adoption Act 1955 tidak mewajibkan meminta pandangan kanak-kanak untuk ditentukan tetapi membenarkan atas faktor pertimbangan untuk diberi kepada kehendak kanak-kanak, berdasarkan kepada umur dan pemahaman kanak-kanak itu. Kerana ketika akta ini diluluskan, kebanyakan jenis permohonan anak angkat adalah melibatkan bayi. Maka tidak ada keperluan mandatori bagi mendapatkan pandangan kanak-kanak dalam urusan tersebut. Sekarang, kanak-kanak yang lebih besar diambil anak angkat di dalam keluarga angkat. Dalam situasi ini, kalau ia mencukupi untuk melahirkan pandangan, maka menjadi hak untuk melakukannya (Mark Henaghan, 1996: 175).

Perbicaraan tentang penjagaan dan perlindungan yang berkaitan dengan penderaan dan pengabaian tidak memerlukan pandangan kanak-kanak. The Children, Young Persons and Their Families Act 1989, memperuntukkan "berdasarkan pertimbangan perlu diberikan kepada pandangan kanakkanak”. Timbangan perlu diberikan kepada pandangan kanak-kanak tidak akan ditentukan semata-mata oleh umur dan kematangan, tetapi budaya kanakkanak itu sendiri. Jika seorang kanak-kanak datang daripada budaya yang memberi kanak-kanak kurang bercakap di dalam membuat keputusan, maka pandangan kanak-kanak akan diberi kurang pertimbangan berbanding dengan kanak-kanak yang datang dari budaya yang banyak memberi kanak-kanak bercakap dalam membuat keputusan. Menurut Mark Henaghan (1996:175), timbangan mengikut kebudayaan ini tidak konsisten dengan KHKK yang terpakai untuk semua kanak-kanak.

Walau bagaimanapun, dalam The Family Protection Act 1955, kanak-kanak mempunyai lebih hak untuk memberikan pandangan ke atas isu kewangan dan harta di atas kematian ibu bapa. Akta ini membenarkan kanak-kanak untuk melawan wasiat ibu bapa berdasarkan tidak diberikan peruntukan mencukupi. Sebaliknya bagi kes berhubung nafkah anak, tidak ada peruntukan dalam Child Support Act 1991 yang mengambil kira pandangan kanak-kanak, bahkan Mark 
Henaghan (1996; 175 \& 177) mengatakan akta ini adalah salah satu contoh klasik bahawa keutamaan ibu bapa mengatasi keutamaan anak.

Di Switzerland, Oliver Guillod (1996: 234) mendapati Civil Code tidak memaksa mahkamah daerah (Canton) untuk mendengar pandangan kanakkanak di dalam perbicaraan bagi kes perceraian atau perpisahan. Draf pertama rang undang-undang Civil Code menilai semula peruntukan perkahwinan dan perceraian serta memperbaiki kedudukan undang-undang kanakkanak di dalam perbicaraan kes perceraian dan perpisahan. Perkara 144 (2) memperuntukkan bahawa hakim akan mendengar pandangan anak (pasangan yang akan bercerai) secara personal dan dalam keadaan yang bersesuaian, selagi mana umur atau lain-lain sebab tidak mengasingkan pandangan peribadi atau meminta pandangan kanak-kanak didengar melalui seorang wakil. Begitu juga dalam kes kanak-kanak yang diletakkan dengan keluarga angkat menurut Perkara 310, Civil Code, tidak ada pandangan daripada aspek undangundang (judicial review) yang dijamin dan sebenarnya tidak ada pun di dalam mahkamah daerah.

Di Denmark, Akta Pengangkatannya lebih kuat daripada Artikel 12 KHKK kerana peruntukan di dalamnya memberikan hak kepada kanak-kanak berusia 12 tahun menolak untuk diambil sebagai anak angkat,termasuk syarat-syarat lain yang lebih ketat. Walaupun hubungan antara anak dengan ibu bapa kandungnya terputus disebabkan pengangkatannya, tetapi jika terdapat ibu bapa kandung yang tidak mahu memutuskan terus hubungannya dengan si anak dan masih mahu menziarahinya, maka hak penjagaan boleh diberikan kepada salah seorang ibu bapa ini dengan syarat semua pihak bersetuju termasuk ibu bapa angkat anak tersebut. Cuma, dalam hal ini, si anak tidak diberikan hak untuk mendengar pendapatnya. Kesemua orang dewasa yang terlibat di dalam proses perpindahan hak jagaan ini akan dipanggil untuk dimaklumkan kesan perpindahan penjagaan ini di sisi undang-undang. Anak-anak angkat ini tidak akan terabai jika ibu bapa angkatnya meninggal dunia kerana Gabenor Daerah diberi kuasa di bawah Minors' Act, s. 15 (Act on Custody s. 14) untuk melantik ibu bapa angkat baru sebagai ganti (Linda Nielsen dan Lis Frost, 1996: 87- 88).

\section{PERKARA 27 (4): PERLAKSANAAN PEMBAYARAN NAFKAH ANAK}

Artikel 27 KHKK memperuntukkan ukuran perlaksanaan untuk menjamin nafkah kanak-kanak daripada ibu bapa. Di Jepun, masalah paling utama bagi ibu yang mendapat hak penjagaan ialah bagaimana memastikan pembayaran nafkah si anak, kerana ada bekas suami tidak pernah membayar nafkah anak. 
Ada yang membayar separuh jalan tetapi ada juga yang konsisten membayar nafkah anak (Yukiko Matshushima, 1996: 138).

Dalam kebanyakan kes, nafkah tidak dibayar disebabkan maksud perlaksanaan perintah yang tidak berkesan. Bahkan di dalam kes perceraian dengan kebenaran, tidak ada langkah perlaksanaan disediakan. Penulis artikel ini mencadangkan agar dibuat beberapa perubahan berkenaan cara pembayaran dan perlaksanaannya. Contohnya, kedua-dua pihak boleh diminta untuk menandatangani dan memfailkan persetujuan untuk menunaikan tanggungjawab setiap pihak kepada pembayaran tersebut. Bahkan, untuk membentuk satu sistem penguatkuasaan yang kukuh, ia mungkin lebih berkesan untuk membuat satu sistem seperti di Sweden iaitu kerajaan membayar kos pembesaran anak bagi pihak dua ibubapa atau salah satu pihakSistem baru ini penting untuk memastikan pengiktirafan prinsip-prinsip bahawa, kemudian pihak ini mesti membayar semula kepada kerajaan yang dianggap sebagai pinjaman kerajaan. ibu bapa mempunyai persamaan tanggungjawab utama dalam membesarkan anak-anak. Isu-isu ini sedang dipertimbangkan oleh Komisyen Undang-undang (Law Commision) (Yukiko Matshushima, 1996: 138-139).

Berdasarkan kepada kajian di atas, ternyata ia merupakan satu cabaran kepada negara-negara yang menandatangani dan menerimapakai triti KHKK 1989 ini dalam memastikan undang-undang domestik negara berkenaan yang berkaitan kanak-kanak memenuhi semua peruntukan yang telah digariskan berdasarkan standard KHKK, terutama jika undang-undang domestik berkenaan telah lama dilaksanakan berbanding KHKK 1989. Usaha menyemak semula peruntukan undang-undang domestik sedia ada perlu dilakukan dengan membuat pindaan peruntukan sedia ada atau memansuhkan peruntukan yang ternyata bertentangan dengan standard KHKK dan dimasukkan peruntukan baru supaya undang-undang domestik berkenaan selaras dengan standard KHKK.

\section{RUJUKAN}

Yukiko Matshushima (1996). "Controversies and Dilemmas: Japan Confronts Convention," Children's Rights: A Comparative Perspective, ed. Michael Freeman. England: Dartmouth Publishing Company Limited, 124-144

Luis Filipe Sacremento \& Ana Maria Pessoa (1996). "Implementation of the Rights of the Child in the Mozambique Context," Children's Rights: A Comparative Perspective. England: Dartmouth Publishing Company Limited, 145-164. 
Olga Khazova (1996). "The UN Convention on the Rights of the Child and Russian Family Law," Children's Rights: A Comparative Perspective. England: Dartmouth Publishing Company Limited, 209-222.

Cecilia P.Grosma (1996). “Argentina-Children's Rights in Family Relationships: The Gulf Between Law and Social Reality," Children's Rights: A Comparative Perspective. England: Dartmouth Publishing Company Limited, 7-32.

Wanda Stojanowska \& Elżbieta Holewińska-Łapińska (1996). "Children's Rights in Poland Three Years after the Convention," Children's Rights: A Comparative Perspective. England: Dartmouth Publishing Company Limited, 197-208.

Linda Nielsen \& Lis Frost (1996). "Children and the Convention: The Danish Debate," Children's Rights: A Comparative Perspective. England: Dartmouth Publishing Company Limited, 65-92.

Mark Henaghan (1996). "New Zealand and The United Nations Convention on the Rights of the Child: A Lack of Balance," Children's Rights: A Comparative Perspective. England: Dartmouth Publishing Company Limited.

Olivier Guillod (1996). "Swiss Law and the United Nations Convention on the Rights of the Child," Children's Rights: A Comparative Perspective. England: Dartmouth Publishing Company Limited, 223-242.

Coby de Graaf (1996). "The Relevance of the Convention on the Rights of the Child in Holand," Children's Rights: A Comparative Perspective. England: Dartmouth Publishing Company Limited, 113-124.

Stephne J.Toope (1996). "The Convention on the Rights of the Child: Implications for Canada," Children's Rights: A Comparative Perspective. England: Dartmouth Publishing Company Limited, 33-64.

Michael Freeman (1996). "The Convention: An English Perspective," Children's Rights: A Comparative Perspective. England: Dartmouth Publishing Company Limited, 93-112.

\section{Senarai Statut}

Adoption Act 1955.

Child Support Act 1991.

Guardianship Act 1968.

Status of Children Amendment Act 1987.

The Children, Young Persons and Their Families Act 1989. 
The Family Protection Act 1955. 
Journal of Shariah Law Research (JSLR) 